\title{
Preparation and Characterization of Nanoliposomal Beta- Cryptoxanthin and its Effect on Proliferation and Apoptosis in Human Leukemia Cell Line K562
}

\author{
Amir Gharib ${ }^{1 *}$, Zohreh Faezizadeh ${ }^{1}$ and Masoud Godarzee ${ }^{2}$ \\ ${ }^{1}$ Department of Laboratory Sciences, Borujerd Branch, Islamic Azad University, Borujerd, Iran, ${ }^{2}$ Department of Biology, \\ Borujerd Branch, Islamic Azad University, Borujerd, Iran
}

*For correspondence: Email: amirgharib@gmail.com; Tel: +986623500201; Fax: +986624453013

Received: 22 October 2014

Revised accepted: 16 January 2015

\begin{abstract}
Purpose: To prepare beta-cryptoxanthin-loaded nanoliposomes and evaluate their anti-proliferative activity in leukemia K562 cell line, compared to free beta-cryptoxanthin.

Methods: Beta-cryptoxanthin-loaded nanoliposomes were prepared by extrusion method. Morphological characterization of the nanoliposomes was performed by cryo-transmission electron microscopy (cryo-TEM). The anti-proliferation effect of beta-cryptoxanthin $(B C)$ in free and liposomal forms on K562 cell line was studied using 3-(4, 5-dimethylthiazol-2-yl)-2, 5-diphenyl tetrazolium bromide assay. Apoptotic activity, following treatment with beta-cryptoxanthin in the free and liposomal forms, was detected using flow cytometry.

Results: Entrapment efficiency of beta-cryptoxanthin was $86.3 \% \pm 1.0$. Cryo-TEM analysis revealed that the nanoliposomes have spherical shapes. In all conditions, beta-cryptoxanthin-loaded nanoliposomes exhibited greater anti-proliferative activity than than the free beta-cryptoxanthin $(p<$ 0.001). Furthermore, in the presence of beta-cryptoxanthin-loaded nanoliposomes, the proportion of apoptotic cells was higher for free beta-cryptoxanthin $(p<0.001)$.

Conclusion: The data obtained indicate that beta-cryptoxanthin, especially in the liposomal form, inhibits the growth of K562 cells and may therefore provide a basis for the development of leukemia therapies.
\end{abstract}

Keywords: Beta-cryptoxanthin, Nanoliposome, Anti-proliferative, Apoptosis, Flow cytometry, Leukemia

Tropical Journal of Pharmaceutical Research is indexed by Science Citation Index (SciSearch), Scopus, International Pharmaceutical Abstract, Chemical Abstracts, Embase, Index Copernicus, EBSCO, African Index Medicus, JournalSeek, Journal Citation Reports/Science Edition, Directory of Open Access Journals (DOAJ), African Journal Online, Bioline International, Open-J-Gate and Pharmacy Abstracts

\section{INTRODUCTION}

Beta-cryptoxanthin (Fig 1) is one of the six major carotenoids routinely present in some yellow or orange fruits and vegetables, such as pumpkin, orange, sweet potatoes, corn and peas [1]. Like other carotenoids, beta-cryptoxanthin can help prevent free radical damage to biomolecules, as well as play an important role in the treatment of certain cancers [2]. It is documented that betacryptoxanthin has an inhibitory effect on different types of cancer cells including lung, bladder, breast, and colon cancer cells $[3,4]$. However, the insolubility of the beta-cryptoxanthin in water has restricted its use in biomedical research [5].

Some studies have shown that encapsulation of plant-derived compounds in nanocarriers markedly compensated their water insolubility and altered their pharmacokinetics and effectiveness [6]. Liposomes are spherical and colloidal vesicles that range from a few 
<smiles>CC1=C(/C=C/C(C)=C/C=C/C(C)=C/C=C/C=C(C)/C=C/C=C(C)/C=C/C2=C(C)CC(O)CC2(C)C)C(C)(C)CCC1</smiles>

Figure 1: Chemical structure of beta-cryptoxanthin

nanometers to several micrometers in diameter [7]. These carriers are composed of natural phospholipids and other lipids, such as cholesterol, and can be used as a vehicle for the administration of drugs and nutrients $[8,9]$. To date, the anti-proliferative activity of betacryptoxanthin in the free and nanoliposomal forms against K562 cell line have not yet been studied. The aim of this study was to prepare beta-cryptoxanthin-loaded nanoliposomes and evaluate their in vitro anti-proliferation activity against the K562 cell line.

\section{EXPERIMENTAL}

\section{Materials}

Fetal bovine serum (FBS), RPMI-1640, penicillin, streptomycin, and trypan blue were obtained from Gibco BRL (Gaithersburg, MD, USA). Betacryptoxanthin (purity $\geq 97 \%$ ). Hoechst 33342 , soy lecithin and cholesterol were purchased from Sigma (St Louis, MO, USA). Ethanol, acetonitrile and diethylamine were obtained from Merck (Darmstadt, Germany).

\section{Preparation of beta-cryptoxanthin-loaded nanoliposomes}

Beta-cryptoxanthin-loaded nanoliposomes were prepared by extrusion method, as described previously [10]. In brief, soy lecithin and cholesterol (4:1 molar ratio) were dissolved in chloroform and then dried to a lipid film with a rotary evaporator (Brinkman) under vacuum and nitrogen flow at $30{ }^{\circ} \mathrm{C}$. Subsequently, the dried lipids were dispersed by agitation in $1 \mathrm{~mL}$ of beta-cryptoxanthin solution $(100 \mu \mathrm{g} / \mathrm{mL})$ and sonicated at $4{ }^{\circ} \mathrm{C}$ in ultrasonic bath (Braun-sonic 2000). Finally, beta-cryptoxanthin-loaded nanoliposomes were obtained by extruding of liposomal suspension through a polycarbonate membrane with $100 \mathrm{~nm}$-sized pores 10 times, and separating the excess free betacryptoxanthin and larger lipid aggregation by ultracentrifugation $(100,000 \mathrm{~g}, 30 \mathrm{~min})$. The control nanoliposomes were prepared similarly, but PBS (pH 7.4) was used instead of the betacryptoxanthin solution.

\section{Characterization of nanoliposomes}

The content of the beta-cryptoxanthin in the nanoliposomes was determined by HPLC method [11] following dissolution in $0.1 \%$ Triton $X-100$. To determination of beta-cryptoxanthin, $20 \mu \mathrm{L}$ of the nanoliposomal lysate was injected into the HPLC column. In the HPLC analysis, a C 18 column $(4.5 \times 150 \mathrm{~mm}, 5 \mu \mathrm{m}$, Phenomenex, Torrance, USA) and diode array UV detector was used. The mobile phase was an equivolume solution of ethanol and acetonitrile containing 0.1 $\mathrm{mL}$ of diethylamine per liter of solvent at a flow rate of $0.9 \mathrm{~mL} / \mathrm{min}$. Subsequently, the loading $(L)$ of beta-cryptoxanthin was calculated as in Eq 1 .

$L(\%)=\{(\mathrm{WnV}) /(\mathrm{VWi})\} 100$

where $\mathrm{Wn}$ is the amount of beta-cryptoxanthin in nanoliposomes, $\mathrm{V}$ the total sample volume tested and $\mathrm{Wi}$ the initial amount of beta-cryptoxanthin used in preparing the nanoliposomal formulation.

The mean particle size, zeta-potential, size distribution, and polydispersity index of the nanoliposomes were evaluated using a Malvern zetasizer (Malvern instrument) apparatus, as reported previously [8]. The analysis of the size and structure of the beta-cryptoxanthin-loaded nanoliposomes were carried out by cryo-TEM, as described previously [12]. Briefly, diluted nanoliposome samples were placed on a copper grid at room temperature and blotted with blotting paper. The sample was transferred to a grid holder and vitrified in liquid nitrogen. Thereafter, digital imaging was performed at $200 \mathrm{kV}$ and size analysis was carried out with the aid of an image analysis software (NIH, Bethesda, MD, USA).

\section{In vitro release study}

The beta-cryptoxanthin released from the nanoliposomes was measured by the reported method [13]. Briefly, a cellulose membrane (molecular weight cut-off of $8000 \mathrm{kDa}$ ) was mounted between the donor and receptor compartments. The donor medium consisted of 1 $\mathrm{mL}$ of nanoliposomal sample and the receptor medium consisted of $10 \mathrm{~mL}$ of citrate-phosphate buffer $(0.1 \mathrm{M}, \mathrm{pH} 7.4)$. During the dialysis, the 
temperature was kept at $37{ }^{\circ} \mathrm{C}$. At predetermined time intervals, between 2 to $12 \mathrm{~h}$, the amount of the released beta-cryptoxanthin was analyzed using HPLC as described above.

\section{Cell culture}

The K562 cell line (human CML, NCBI-C122) was purchased from Pasteur Institute of Iran (Tehran, Iran). The cells were grown in RPMI1640 medium supplemented with $10 \%$ (vol/vol) heat inactivated FBS along with penicillin (100 units $/ \mathrm{mL})$ and streptomycin $(100 \mu \mathrm{g} / \mathrm{mL})$ and were maintained at $37^{\circ} \mathrm{C}$ in a humidified incubator $5 \% \quad \mathrm{CO}_{2}$. Beta-cryptoxanthin was dissolved in DMSO to obtain a $1 \mathrm{mg} / \mathrm{mL}$ stock solution. All subsequent dilutions were made in the RPMI medium.

\section{Cell proliferation assay}

In this test, K562 cell proliferation was evaluated using the 3-(4, 5-dimethylthiazol-2-yl)-2, 5diphenyl tetrazolium bromide (MTT) assay as described previously [14]. Briefly, $5 \times 10^{3}$ cells were incubated in 96 well plates in the presence of different concentrations of beta-cryptoxanthin in the free and nanoliposomal forms $(0,10,50$ and $100 \mu \mathrm{g} / \mathrm{mL}$ ) for 24,48 , and $72 \mathrm{~h}$ in a final volume of $200 \mu \mathrm{L}$. At the end of the treatment period, $20 \mu \mathrm{L}$ aliquots of MTT solution $(5 \mathrm{mg} / \mathrm{mL}$ in PBS) was added to each well, and the plates were incubated at $37{ }^{\circ} \mathrm{C}$. Subsequently, the purple-blue MTT formazan precipitate was dissolved in $200 \mu \mathrm{l}$ of DMSO and the optical density read at $570 \mathrm{~nm}$. Three replicates of each concentration of beta-cryptoxanthin in the free and nanoliposomal forms were performed.

\section{Nuclear staining with Hoechst 33342}

The K562 cells were incubated with betacryptoxanthin in the free and encapsulated forms $(0,10,50$ and $100 \mu \mathrm{g} / \mathrm{mL})$ for $72 \mathrm{~h}$ and washed with PBS buffer. After fixing in freshly prepared ice-cold paraformaldehyde $(0.1 \%)$ for $10 \mathrm{~min}$, the K562 cells were then stained with Hoechst $33342(50 \mu \mathrm{g} / \mathrm{mL})$ for $1 \mathrm{~min}$ and its morphologic changes were observed under the fluorescent microscope. Subsequently, the percentage of apoptotic cells was determined. This experiment was done in triplicate.

\section{Flow cytometric analysis}

The K562 cells were treated with varying concentrations of beta-cryptoxanthin in the free and nanoliposomal forms (10, 50 and 100 $\mu \mathrm{g} / \mathrm{mL}$ ) in complete medium for $72 \mathrm{~h}$. After treatment, the cells were collected and the quantitative apoptotic death assay was done using Annexin $\mathrm{V}$ and $\mathrm{Pl}$ staining following the manufacturer's protocol. Subsequently, the stained cells were analyzed by flow cytometer using FACS (BD, San Diego, CA, USA).

\section{Statistical analysis}

All data were expressed as means \pm standard deviation (SD). The analysis of variance was performed to determine the significance level among the tested groups using IBM Statistics SPSS software version 19, and $p<0.05$ was considered statistically significant.

\section{RESULTS}

The results showed that the percentage of betacryptoxanthin entrapment efficacy was $86.3 \% \pm$ 1. Table 1 shows mean particle size, zetapotential, and polydispersity index of empty and beta-cryptoxanthin-loaded nanoliposomes. According to previous studies, the size homogeneity of empty and loaded nanoliposomes suggested that betacryptoxanthin was entrapped into nanoliposomes $[9,10]$. Furthermore, the polydispersity index of the nanoliposomes revealed that the prepared nanoliposomes have appropriate stability in aqueous dispersion [12].

Cryo-TEM analysis showed that the nanoliposomes have a fine spherical shape and homogeneity (Fig 2).

Table 1: Particle size, zeta-potential and polydispersity index of empty and beta-cryptoxanthin-loaded nanoliposomes

\begin{tabular}{lccc}
\hline Formulation & $\begin{array}{c}\text { Mean particle } \\
\text { size }(\mathbf{n m})\end{array}$ & $\begin{array}{c}\text { Zeta-potential } \\
(\mathbf{m V})\end{array}$ & $\begin{array}{c}\text { Polydispersity } \\
\text { index }\end{array}$ \\
\hline Empty nanoliposomes & $93.5 \pm 0.25$ & $-1.12 \pm 0.10$ & $0.18 \pm 0.06$ \\
$\begin{array}{l}\text { Beta-cyptoxanthin- } \\
\text { loaded nanoliposomes }\end{array}$ & $96.2 \pm 0.18$ & $-1.44 \pm 0.21$ & $0.18 \pm 0.04$ \\
\hline
\end{tabular}




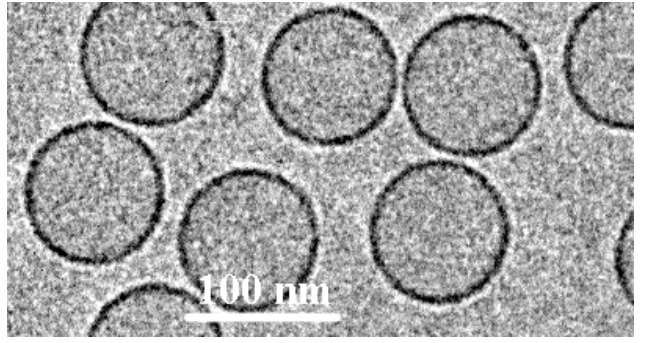

Figure 2: Cryo-transmission electron micrographs of the nanoliposomes loaded with beta-cryptoxanthin

The released amount of beta-cryptoxanthin at 37 ${ }^{\circ} \mathrm{C}$ from nanoliposomes was plotted as a function of time (Fig 3). Beta-cryptoxanthin recovery after $12 \mathrm{~h}$ was $84.1 \% \pm 1.8$. The data suggest that the prepared nanoliposomes would be stable at the body temperature.

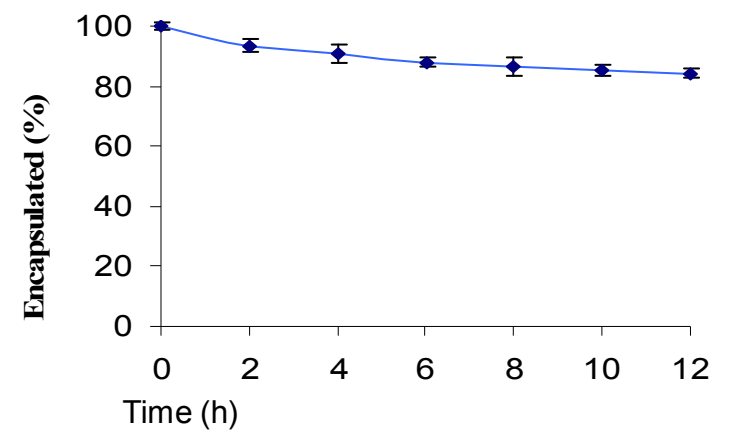

Figure 3: Recovery of beta-cryptoxanthin in nanoliposomes at $37^{\circ} \mathrm{C}$

The viability of the K562 cells after treatment with the free and nanoliposomal forms of betacryptoxanthin was examined by MTT assay. The data showed that cell proliferation was inhibited in K562 cells in a dose- and time-dependent manner (Fig 4). In all conditions, the betacryptoxanthin-loaded nanoliposomes were more effective than those of free beta-cryptoxanthin on the K562 cell proliferation $(p<0.001)$. As shown in Figure 4, the extent of inhibition increased significantly at $24 \mathrm{~h}$ with the lowest concentration of beta-cryptoxanthin in the free and encapsulated forms which was continued to rise at 48 and $72 \mathrm{~h}$ durations at their maximum concentration.

The Hoechst staining of the beta-cryptoxanthintreated cells after $72 \mathrm{~h}$ showed characteristic apoptotic features such as nuclear fragmentation and chromatin condensation (Fig 5). In particular, in the presence of beta-cryptoxanthin-loaded nanoliposomes the percentage of the apoptotic cells was higher than those of free betacryptoxanthin $(p<0.001)$.
As shown in the representative FACS analysis scatter-grams, the treated cells with betacryptoxanthin, in particular in the loaded form, at 10,50 and $100 \mu \mathrm{g} / \mathrm{mL}$ doses for $72 \mathrm{~h}$ showed a strong shift from the vital cells to the late and early apoptotic cells with a little change in the necrotic cell population (Fig 6).

\section{DISCUSSION}

The use of plant-derived materials for cancer therapy has been widely investigated $[15,16]$. The main problem associated with the application of such compounds is insufficient water solubility [17].

As an interesting approach to drug delivery research, the incorporation of plant-derived materials into nanoparticles could overcome this limitation [18]. It has been reported that encapsulation of plant-derived materials in the liposomes could increase their water solubility, bioavailability and effectiveness $[19,20]$.

Beta-cryptoxanthin, a carotenoid pigment and phytochemical, is naturally present in many vegetables and fruits such as apricots, grapefruit, tangerines and rutabagas [1,2]. Evidence for beta-cryptoxanthin's benefit was strongest for anti-oxidative, anti-tumour, anti-inflammatory, and anti-arthritis effects [4,5]. In this study we found that beta-cryptoxanthin, in particular in the encapsulated form, significantly inhibited proliferation of K562 cells with a dose- as well as time-dependent manner. Our results showed that anti-proliferation of beta-cryptoxanthin-loaded nanoliposomes against K562 cells was higher than those of free beta-cryptoxanthin. Several hypotheses, including increased water suspensibility and penetration of plant-derived compounds into cells may explain the mechanism of enhanced anticancer efficacies of these nanovesicle formulations [15-20]. When nanocarriers such as nanoliposomes were used in vitro, they can interact with the cancer cell membranes, and therefore they can selectively deliver drugs to the cancer cells $[19,20]$.

In this case, similar observations have been reported in some previous studies with other natural plant products such as curcumin [15], epigallocatechin-3-gallate [16], celastrol [17], tea polyphenol [18], berberine [19] and gossypol [20] in various cancer cell lines. Therefore, betacryptoxanthin and other effective plant-derived agents, in particular in loaded form, could be considered as a promising strategy for developing anticancer drugs. 
a

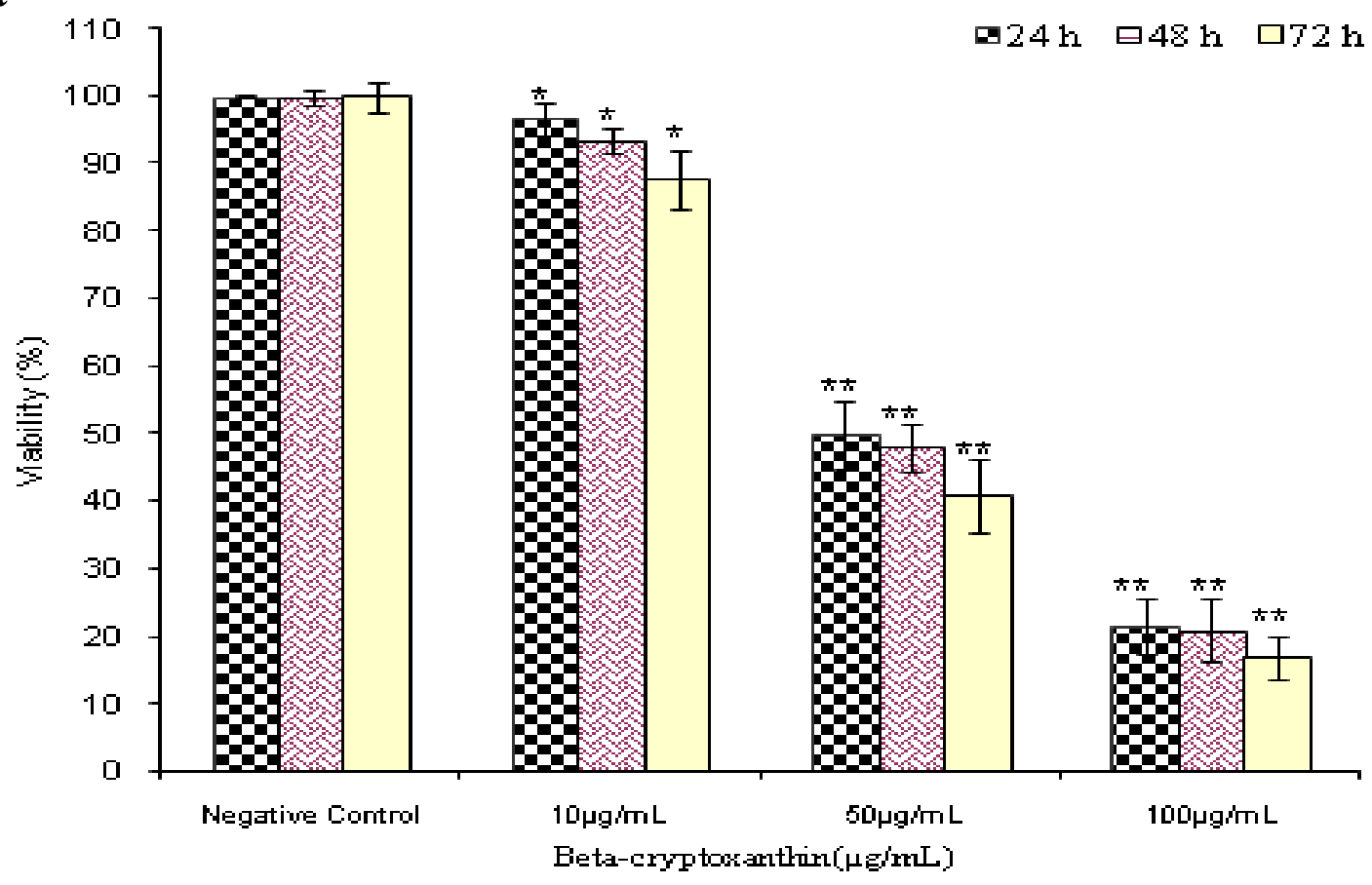

b

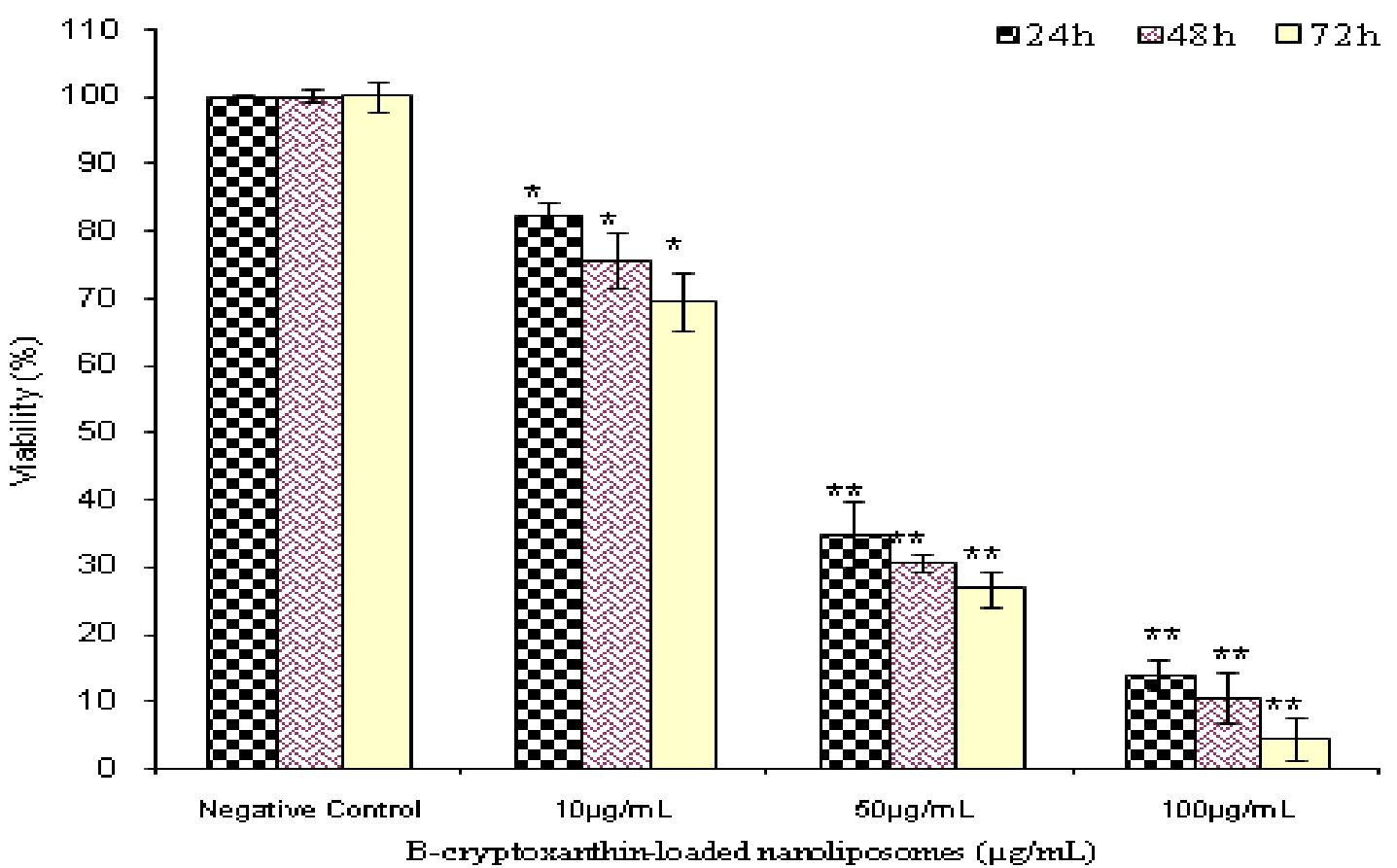

Figure 4: Dose- and time-dependent inhibition of K562 cell growth by beta-cryptoxanthin in the free (a) and nanoliposomal (b) forms. The cells were incubated with increasing concentration of beta-cryptoxanthin in the free and nanoliposomal forms and then the cell survival was determined by 3-(4, 5-dimethylthiazol-2-yl)-2, 5-diphenyl tetrazolium bromide assay. Data are expressed as mean \pm standard deviation $\left(n=3,{ }^{*} p<0.05,{ }^{* *} p<0.001\right)$ 
GFree beta-cryptoxanthin

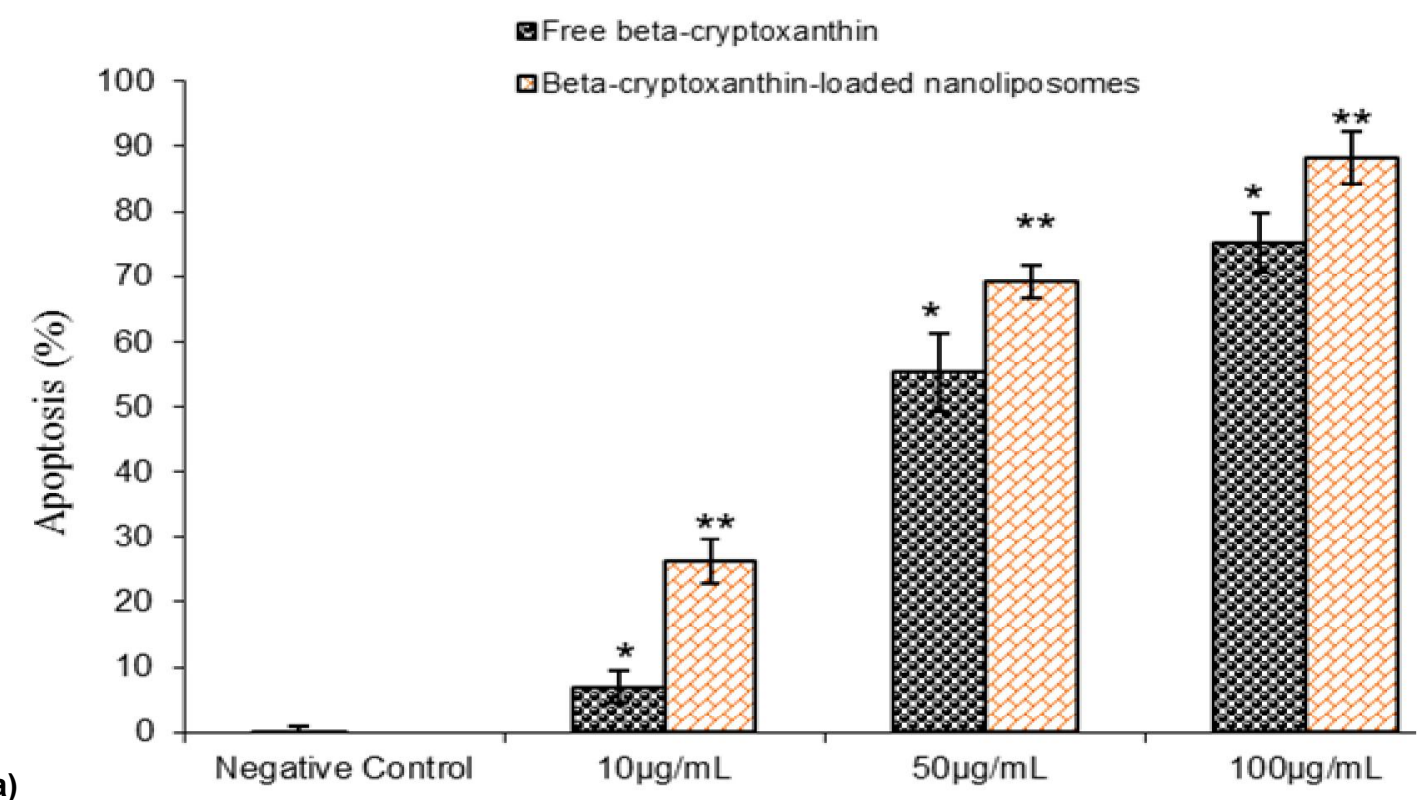

(a)
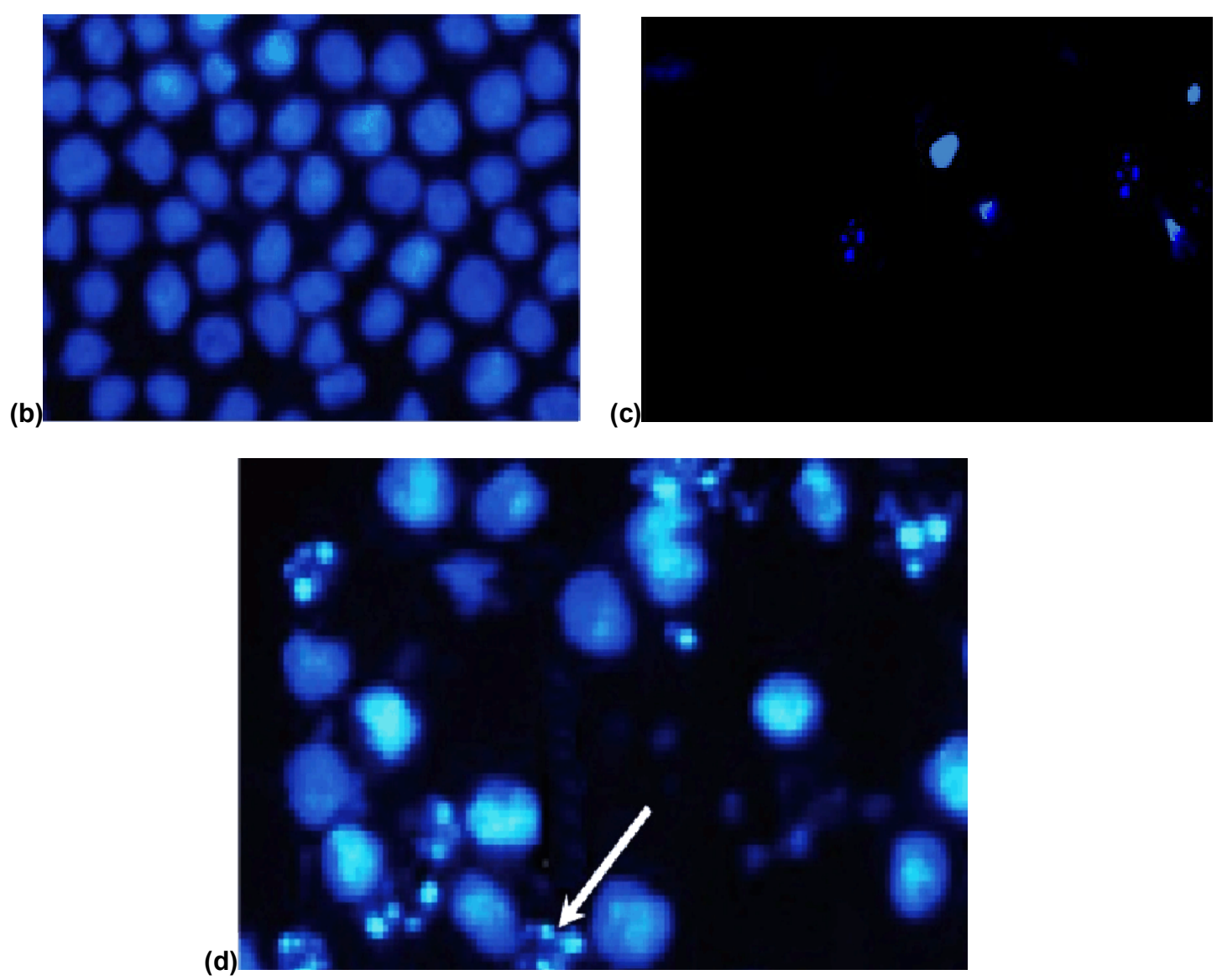

Figure 5: (a) Rate of apoptotic K562 cells after treatment with beta-cryptoxanthin in the free and nanoliposomal forms; (b) control cells; (c) fragmented or condensed nuclei indicative of apoptosis in the beta-cryptoxanthintreated cells with free form; and (d) with nanoliposomal forms, as indicated with arrows. Data represent mean \pm standard deviation $\left(\mathrm{n}=3,{ }^{*} p<0.05,{ }^{* *} p<0.001\right)$ 
(a)

B eta-cryptoxanthin $(10 \mu \mathrm{g} / \mathrm{mL})$

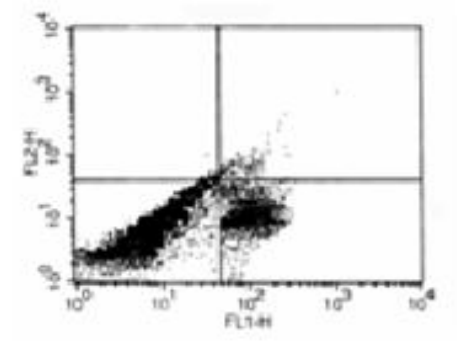

Quad \%Total

UL $\quad 0.94$

UR $\quad 2.10$

LL $\quad 89.26$

LR $\quad 7.70$
Beta-cryptoxanthin ( $50 \mu \mathrm{g} / \mathrm{mL}$ )

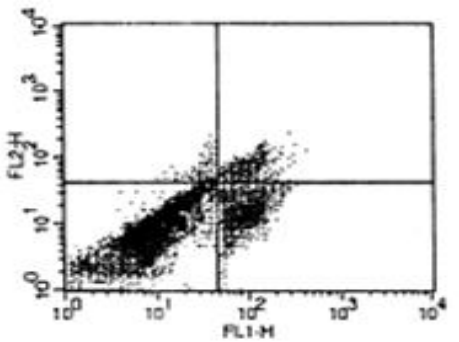

Quad \%Total

UL $\quad 5.08$

UR $\quad 13.91$

LL $\quad 38.75$

LR $\quad 42.26$
Beta-cryptoxanthin $(100 \mu \mathrm{g} / \mathrm{mL})$

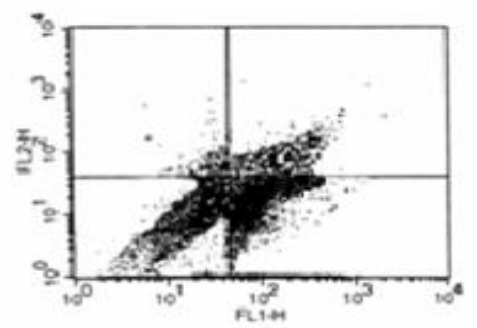

Quad \%Total

UL $\quad 7.02$

UR $\quad 10.19$

LL $\quad 17.65$

LR $\quad 65.14$

(b)

Nanoliposomal BC $(10 \mu \mathrm{g} / \mathrm{mL})$

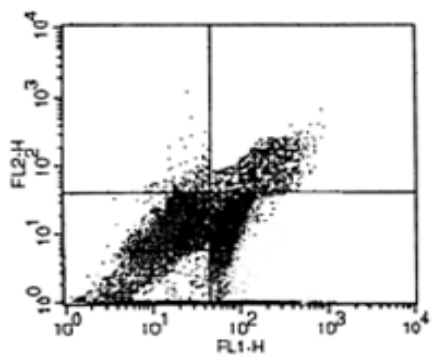

Quad \%Total

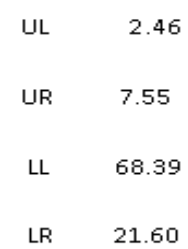

Nanoliposomal BC $(50 \mu \mathrm{g} / \mathrm{mL}) \quad$ Nanoliposomal BC $(100 \mu \mathrm{g} / \mathrm{mL})$
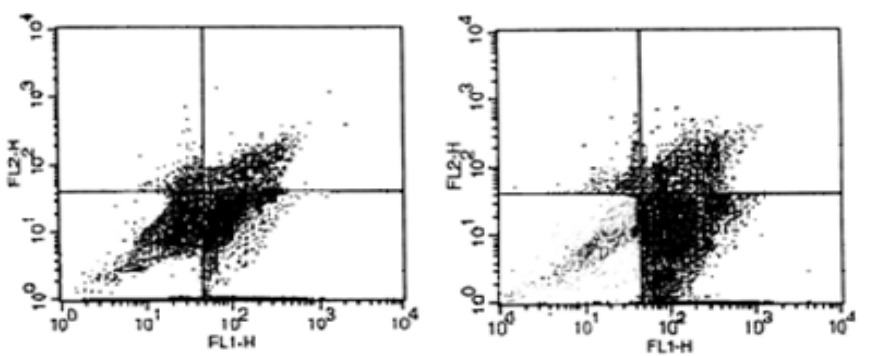

Quad \%Total

$\begin{array}{ll}\text { UL } & 5.89 \\ \text { UR } & 13.78 \\ \text { LL } & 5.15 \\ \text { LR } & 75.18\end{array}$

Figure 6: Representative FACS analysis of treated cells with 10,50 and $100 \mu \mathrm{g} / \mathrm{mL}$ of beta-cryptoxanthin in the free (a), and loaded (b) forms after staning with AnnexinV/PI. Lower Left (LL): AnnexinV PI', Lower Right (LR): AnnexinV ${ }^{+} \mathrm{PI}^{-}$, Upper Right (UR): AnnexinV ${ }^{+} \mathrm{PI}^{+}$, Upper Left (UL): AnnexinV $\mathrm{PI}^{+}$

\section{CONCLUSION}

Findings from this work demonstrate that nanoliposomal beta-cryptoxanthin, can be prepared by extrusion method. Betacryptoxanthin-loaded nanoliposomes have strong apoptosis induction effect in human leukemia cell line K562. Therefore, this novel formulation provides a basis for the future development of leukemia therapies.

\section{ACKNOWLEDGEMENT}

This study was supported by Islamic Azad University, Borujerd Branch, Iran. The authors would like to acknowledge staff of the University. 


\section{REFERENCES}

1. Tanaka T, Tanaka T, Tanaka M, Kuno T. Cancer chemoprevention by citrus pulp and juices containing high amounts of $\beta$-cryptoxanthin and hesperidin. $J$ Biomed Biotechnol 2012; 2012: 516981.

2. Iskandar AR, Liu C, Smith DE, Hu KQ, Choi SW, Ausman $L M$, Wang XD. $\beta$-cryptoxanthin restores nicotinereduced lung SIRT1 to normal levels and inhibits nicotine-promoted lung tumorigenesis and emphysema in A/J mice. Cancer Prev Res (Phila) 2013; 6: 309-320.

3. Wu C, Han L, Riaz H, Wang S, Cai K, Yang L. The chemopreventive effect of $\beta$-cryptoxanthin from mandarin on human stomach cells (BGC-823). Food Chem 2013; 136: 1122-1129.

4. Shimoda H, Shan SJ, Tanaka J, Maoka T. $\beta$ Cryptoxanthin suppresses UVB-induced melanogenesis in mouse: involvement of the inhibition of prostaglandin E2 and melanocytestimulating hormone pathways. J Pharm Pharmacol 2012; 64: 1165-1176.

5. Mustapha $Y$, Babura SR.Determination of carbohydrate and $\beta$-carotene content of some vegetables consumed in Kano-Metropolis, Nigeria.Bayero J Pure Appl Sci 2009; 2: 119-121.

6. Fang JY, Hwang TL, Huang YL, Fang CL. Enhancement of the transdermal delivery of catechins by liposomes incorporating anionic surfactants and ethanol. Int $\mathrm{J}$ Pharm 2006; 310: 131-138.

7. Koohi MEM, Alavi SE, Akbarzadeh A, Ghassemi S, Saffari Z, Farahnak M, Chiani M. Pegylation of Nanoliposomal Paclitaxel Enhances its Efficacy in Breast Cancer. Trop J Pharm Res 2014; 13: 11951198.

8. Gharib A, Faezizadeh Z, Godarzee M. Treatment of diabetes in the mouse model by delphinidin and cyanidin hydrochloride in free and liposomal forms. Planta Med 2013; 79: 1599-1604.

9. Gharib A, Faezizadeh Z, Mesbah-Namin SA. In vitro and in vivo antibacterial activities of cyanidinum chlorideloaded liposomes against a resistant strain of Pseudomonas aeruginosa. Planta Med 2013; 79: 1519.

10. Fang JY, Hwang TL. Enhancement of the transdermal delivery of catechins by liposomes incorporating aionic surfactants and ethanol. Int J Pharm 2006; 310: 131-138.
11. Sowell AL, Huff $D L$, Yeager PR, Caudill SP, Gunter EW. Retinol, alpha-tocopherol, lutein/zeaxanthin, betacryptoxanthin, lycopene, alpha-carotene, trans-betacarotene, and four retinyl esters in serum determined simultaneously by reversed-phase HPLC with multiwavelength detection. Clin Chem 1994; 40: 411 416.

12. Bothun $G D$, Lelis A, Chen $Y$, Scully K, Anderson LE, Stoner MA. Multicomponent folate-targeted magnetoliposomes: design, characterization, and cellular uptake. Nanomedicine 2011; 7: 797-805.

13. Gharib A, Faezizadeh Z, Godarzee M. Therapeutic efficacy of epigallocatechin gallate-loaded nanoliposomes against burn wound infection by methicillin-resistant Staphylococcus aureus. Skin Pharmacol Physiol 2013; 26: 68-75.

14. Campling BG, Pym J, Baker HM, Cole SP, Lam YM. Chemosensitivity testing of small cell lung cancer using the MTT assay. Br J Cancer 1991; 63: 75-83.

15. Hasan M, Belhaj N, Benachour H, Barberi-Heyob M, Kahn CJ, Jabbari E, Linder M, Arab-Tehrany $E$. Liposome encapsulation of curcumin: physicochemical characterizations and effects on MCF7 cancer cell proliferation. Int J Pharm 2014; 461: 519528.

16. de Pace RC, Liu X, Sun M, Nie S, Zhang J, Cai Q, Gao W, Pan X, Fan Z, Wang S. Anticancer activities of (-)epigallocatechin-3-gallate encapsulated nanoliposomes in MCF7 breast cancer cells. J Liposome Res 2013; 23: 187-196.

17. Huang Y, Zhou D, Hang T, Wu Z, Liu J, Xu Q, Xie X, Zuo J, Wang Z, Zhou Y. Preparation, characterization, and assessment of the antiglioma effects of liposomal celastrol. Anticancer Drugs 2012; 23: 515-524.

18. Fang JY, Lee WR, Shen SC, Huang YL. Effect of liposome encapsulation of tea catechins on their accumulation in basal cell carcinomas. J Dermatol Sci 2006; 42: 101-109.

19. Ma X, Zhou J, Zhang CX, LiXY, Li N, Ju RJ, Shi JF, Sun MG, Zhao WY, Mu LM, Yan Y, Lu WL. Modulation of drug-resistant membrane and apoptosis proteins of breast cancer stem cells by targeting berberine liposomes. Biomaterials 2013; 34: 4452-4465.

20. Li H, Piao L, Xu P, Ye W, Zhong S, Lin SH, Kulp SK, Mao $Y$, Cho Y, Lee LJ, Lee RJ, Lin YC. Liposomes containing (-)-gossypol-enriched cottonseed oil suppress $\mathrm{BCl}-2$ and $\mathrm{BCl}-\mathrm{xL}$ expression in breast cancer cells. Pharm Res 2011; 28: 3256-3264. 